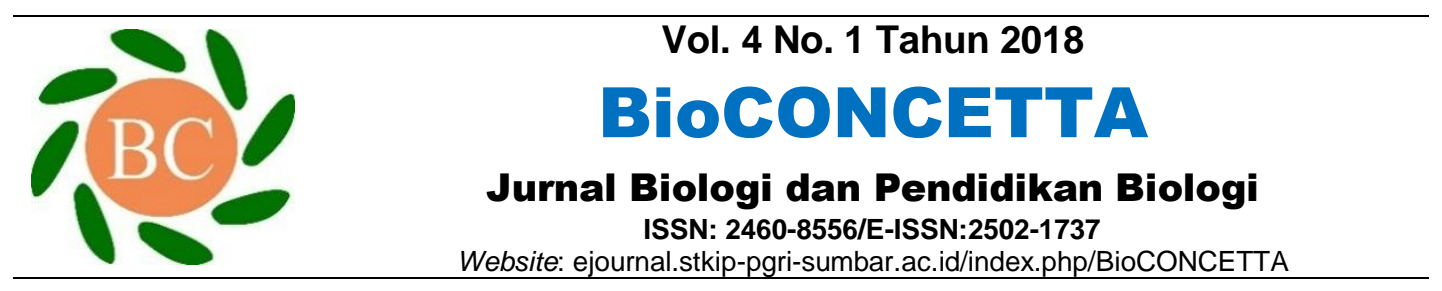

\title{
Pengaruh Pembelajaran Model 5E Melalui Pendekatan Saintifik Terhadap Kemampuan Berargumen Siswa pada Materi Ekologi
}

Muh. Nasir* dan Erni Suryani

Program Studi Pendidikan Biologi STKIP Bima

Jl. Piere Tendean, Mpunda, Nusa Tenggara Barat (84111) Indonesia.

Email: perahubima@gmail.com

\section{Info Artikel}

Sejarah Artikel

Diterima:

23 Juli 2018

Disetujui:

30 Agustus 2018

Dipublikasikan:

31 Agustus 2018

Kata Kunci:

model 5E,

pendekatan Saintifik,

kemampuan

berargumen

Keywords:

5E models, scientific

approach, arguing ability

\begin{abstract}
Abstrak
Penelitian ini bertujuan untuk mengetahui pengaruh pembelajaran model 5E melalui pendekatan saintifik terhadap kemampuan berargumen siswa pada materi ekologi. Desain penelitian menggunakan pretes-posttes non-equivalen control group desain. Populasi penelitian eksperimen adalah siswa kelas X SMA Negeri 1 Woha Bima, sejumlah 10 kelas dengan populasi 350 siswa. Sampel dipilih dengan tehnik simple random sampling dari 10 kelas yang ada diambil 4 kelas sebagai sampel dengan jumlah sampel 131 siswa. Kelas $X_{1}$, dan $X_{2}$, menerapkan pembelajaran model $5 \mathrm{E}$ melalui pendekatan saintifik dan kelas $\mathrm{X}_{5}$, dan $\mathrm{X}_{9}$ menerapkan pembelajaran model EEK. Hasil penelitian menunjukkan terdapat pengaruh yang signifikan pembelajaran model 5E melalui pendekatan saintifik terhadap kemampuan berargumen siswa pada materi ekologi $(\mathrm{t}=4,482, \mathrm{p}=0,000)$.
\end{abstract}

\begin{abstract}
This study aims to determine the effect of $5 E$ learning model through a scientific approach to the ability to argue students on ecological material. The study design used a pretest-posttest non-equivalent control group design. The population of the experimental research was the tenth grade students of Woha Bima 1 State Senior High School, 10 classes with a population of 350 students. The sample was chosen by simple random sampling technique from 10 classes that were taken 4 classes as samples with a sample of 131 students. The students at classes $X_{1}$, and $X_{2}$, apply $5 E$ model learning through scientific approaches and class $X_{5}$, and $X_{9}$ apply EEK model learners. The results showed there was a significant effect of the $5 E$ learning model through a scientific approach to students' ability to argue on ecological material $(t=4.482, p=0.000)$.
\end{abstract}


PENDAHULUAN

Salah satu upaya yang sedang dilakukan pemerintah dalam meningkatkan mutu pendidikan IPA adalah pembelajaran berpusat pada siswa dengan cara menekankan kegiatan inkuiri. Pada kegiatan inkuiri, siswa dilibatkan sebagai pelaku inkuiri secara aktif ketika melakukan observasi, eksplorasi, investigasi, pemodelan, perumusan hipotesis dan eksperimentasi terhadap berbagai gejala alam, sedangkan peran guru dalam pembelajaran IPA sebagai pemandu inkuiri (Anonim, 2011). Kegiatan inkuiri bertujuan untuk meningkatkan kemampuan berpikir. Kemampuan berpikir terdiri dari tiga yaitu berpikir tingkat tinggi, berpikir kompleks dan berargumen (Sutrisno, 2010). Kemampuan berargumen merupakan salah satu bagian dari kemampuan berpikir tingkat tinggi, hal ini sesuai dengan pendapat Mangao (2011), bahwa kemampuan berpikir tingkat tinggi meliputi berargumen, berpikir kreatif, berpikir analitik, pemecahan masalah, mensintesis, mengaplikasi, dan mengevaluasi.

Namun kenyataan yang terjadi pada lembaga-lembaga pendidikan di Indonesia, terutama pada jenjang sekolah dasar dan menengah adalah guru masih kurang memperhatikan aspek keterampilan berpikir dalam proses pembelajaran (Corebima, 2005). Siswa hanya difokuskan pada kegiatan menghafal materi pelajaran. Ketika siswa dihadapkan pada permasalahan yang terjadi di lingkungan sekitarnya, siswa kurang mampu menggabungkan pengetahuan yang dimilikinya untuk mencari penjelasan dan memberikan pendapat berupa solusi dari masalah tersebut menggunakan kemampuan berargumen dan kemampuan berargumen. Pelajaran biologi di sekolah menengah dapat berperan sebagai sarana yang efektif untuk mengembangkan kemampuan berargumen siswa. Kemampuan berargumen merupakan salah satu komponen kecakapan hidup yang dapat dikembangkan melalui proses pembelajaran (Tim BBE, 2003). Pengembangan kemampuan berargumen seharusnya dapat dibantu oleh guru melalui pemilihan dan penerapan model pembelajaran yang dapat melibatkan siswa secara fisik dan mental dalam proses pembelajaran (Deming, 2004).

Berdasarkan hasil wawancara yang dilakukan dengan guru pengajar 
biologi dan beberapa siswa tentang permasalahan pembelajaran biologi di SMA Negeri 1 Woha Bima, dapat diidentifikasi beberapa faktor penyebab rendahnya kemampuan berargumen siswa adalah sebagai berikut: Pertama, model pembelajaran yang digunakan oleh guru dalam pembelajaran biologi sering tidak sesuai dengan perencanaan. Dalam hal ini, model pembelajaran yang dimaksud adalah model pembelajaran EEK yang mengacu pada Permendiknas RI Nomor 41 tahun 2007. Guru memang membuat rencana pelaksanaan pembelajaran sesuai dengan model EEK yang terdiri dari tahap eksplorasi, elaborasi dan konfirmasi, tetapi dalam pelaksanaannya di kelas guru sering mengabaikan tahap-tahap tersebut dan lebih mengacu pada pembelajaran langsung. Kedua, kurangnya motivasi belajar dan konsep diri siswa dapat diamati dari partisipasi siswa di kelas yang sangat kurang. Motivasi dan konsep diri yang lemah dalam belajar terjadi akibat dari permasalahan yang disajikan oleh guru kurang bersifat kontekstual, serta pada awal pembelajaran guru belum menggali pengetahuan awal siswa. Ketiga, sumber belajar biologi yang ada di lingkungan sekitar belum dimanfaatkan secara optimal untuk kepentingan pembelajaran. Guru biologi masih terfokus hanya pada penggunaan buku teks sebagai sumber belajar

Salah satu model pembelajaran yang potensial untuk membantu siswa agar terlibat aktif dalam kegiatan belajar adalah model 5E (Bass et al, 2009). Model 5E merupakan suatu model yang terdiri dari lima tahapan, yaitu engage, exsplore, explain, elaborate, dan evaluate. Setiap tahap model 5E bertujuan untuk membangkitkan rasa ingin tahu siswa. Dasna dan Sutrisno (2005) menyatakan bahwa dalam model 5E siswa mengembangkan pemahamannya terhadap suatu konsep dengan kegiatan mencoba (hand-on activities) sebelum diperkenalkan dengan kata-kata melalui diskusi atau memperoleh informasi dari buku. Oleh sebab itu, model $5 \mathrm{E}$ juga dapat mengembangkan keterampilan proses siswa, memberi kesempatan kepada mereka melakukan percobaan sains secara langsung dan membuat pembelajaran bermakna. Model 5E juga dapat digunakan untuk melatih kemampuan berargumen siswa. Hal tersebut didukung oleh hasil penelitian Fatimah (2012) yang 
menyatakan bahwa model $5 E$ dapat meningkatkan kemampuan berargumen siswa. Chankian (2012) menyatakan bahwa, siswa memiliki keterampilan sains yang lebih baik setelah penerapan pembelajaran model 5E. Selain itu, skor tes berargumen sebagian besar siswa baik kelompok belajar tinggi dan rendah meningkat. Hasil yang baik diperoleh setelah penerapan model pembelajaran $5 \mathrm{E}$ dikarenakan model pembelajaran ini membuat siswa menjadi penasaran untuk belajar dan juga menekankan pada pengembangan kemampuan siswa.

Berdasarkan atas permasalahan tersebut tujuan dari penelitian ini adalah untuk mengetahui pengaruh pembelajaran model 5E melalui pendekatan saintifik terhadap kemampuan berargumen siswa pada materi ekologi.

\section{BAHAN DAN METODE}

Penelitian dilaksanakan di SMA Negeri 1 Woha Kabupaten Bima Nusa Tenggara Barat pada bulan September 2017 dengan menggunakan penelitian quasi eksperiment, desain penelitian Pre-test Post-Test Control- Group. Pengambilan sampel dilakukan dengan teknik simple random sampling yaitu dari 10 kelas yang ada diambil 4 kelas sebagai sampel. Sampel penelitian berjumlah 131 orang siswa yang terdaftar pada semester II kelas X SMA Negeri 1 Woha Bima. Siswa di kelas $\mathrm{X}_{1}$ dan $X_{2}$ diberikan pembelajaran dengan perangkat model $5 \mathrm{E}$ dan kelas $\mathrm{X}_{5}$ dan $\mathrm{X}_{9}$ diberikan pembelajaran dengan perangkat model EEK. Data post-test kemampuan berargumen yang diperoleh ditabulasi kemudian dihitung nilai rata-ratanya.

Tes kemampuan berargumen disusun dalam bentuk pilihan ganda akibat-sebab disertai alasan, yang terdiri dari 22 soal. Instrumen ini digunakan untuk mengukur kemampuan berargumen siswa dalam proses pembelajaran materi ekologi. Indikator yang digunakan pada tes kemampuan berargumen terdiri dari 3 indikator, yaitu; memprediksi mengamati - menjelaskan, klasifikasi, dan menginterpretasi data. Aspekaspek yang diamati dengan lembar tes kemampuan berargumen, yaitu disesuaikan dengan kemampuan yang akan dikembangkan pada siswa.

Data post-test kemampuan berargumen ini digunakan untuk menguji hipotesis. Sebelum uji hipotesis, data terlebih dahulu 
dilakukan uji prasyarat yaitu uji normalitas dengan menggunakan uji Kolmogorof Smirnov dan Uji homogenitas menggunakan Levene test. Hipotesis alternatif (Ha) yang berbunyi "Apakah ada pengaruh pembelajaran model 5E melalui pendekatan saintifik terhadap kemampuan berargumen siswa pada materi ekologi” akan diuji menggunakan uji-t dengan bantuan program komputer SPSS 20 for windows pada taraf signifikan 5\%. Kriteria pengujian hipotesis; Ho ditolak apabila $t_{\text {hitung }}>t_{\text {tabel }}$ atau nilai $p>0,05$ maka Ho diterima, demikian sebaliknya jika $\mathrm{p}<0,05$ maka Ho ditolak.

Untuk mengetahui peningkatan kemampuan berargumen siswa setelah penerapan perangkat pembelajaran model 5E, maka digunakan gain score.

\section{HASIL DAN PEMBAHASAN}

\section{Kemampuan Berargumen}

Data kemampuan berargumen yang dideskripsikan dalam penelitian ini adalah skor rata-rata yang diperoleh subjek penelitian dari tes kemampuan berargumen pada materi ekologi kelas X SMA. Skor rata-rata kemampuan berargumen kemudian diklasifikasi kedalam 5 kategori yaitu, Nilai 40,0051,40 dikategorikan Sangat Kurang, 51,41-62,90 kategori Kurang, 62,9174,30 kategori Sedang, 74,31-85,70 kategori Baik, dan $\geq 85,71$ Gronlund dan Linn dalam Jufri, (2010). Rata-rata skor kemampuan berargumen siswa dengan pembelajaran model $5 \mathrm{E}$ dan pembelajaran model EEK disajikan sebagai pada Gambar 1.

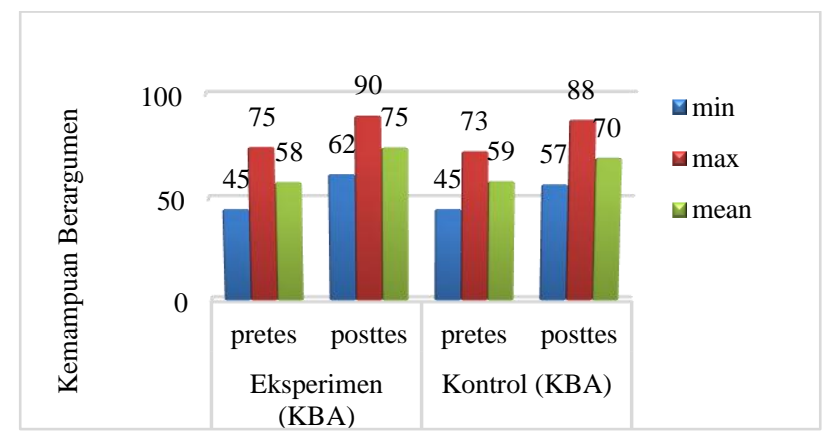

Gambar 1. Diagram Batang Rerata Skor Kemampuan Berargumen

Berdasarkan Gambar 1 dapat 5E yang diterapkan pada kelas diketahui bahwa pembelajaran model eksperimen mempunyai 
kecenderungan untuk meningkatkan kriteria nilai kemampuan berargumen, hal ini terlihat dari rata-rata nilai pretes kemampuan berargumen siswa sebesar 58 dengan kategori kurang, kemudian mengalami peningkatan setelah dilakukan pembelajaran dengan model 5E melalui pendekatan saintifik sebesar 75 , nilai ini berada pada kategori baik. Selanjutnya rerata nilai kemampuan berargumen pada kelas kontrol yang menggunakan pembelajaran model EEK yang biasa dipakai di sekolah juga mengalami peningkatan dari 59 dengan kategori kurang menjadi 70 pada kategori sedang.

Sebaran persentase peningkatan kemampuan berargumen siswa pada tiap kategori ditunjukkan pada Tabel 1.

Tabel 1. Persentase Sebaran Nilai Kemampuan Berargumen Berdasarkan N-gain

\begin{tabular}{lccccccc}
\hline \multirow{2}{*}{ Perlakuan } & \multirow{2}{*}{$\mathrm{N}$} & \multicolumn{2}{c}{ Tinggi } & \multicolumn{2}{c}{ Sedang } & \multicolumn{2}{c}{ Rendah } \\
\cline { 3 - 8 } & & Jumlah & Persentase & Jumlah & Persentase & Jumlah & Persentase \\
\hline Eksperimen & 66 & 1 & $1,52 \%$ & 51 & $77,27 \%$ & 14 & $21,21 \%$ \\
\hline Kontrol & 65 & 0 & $0,00 \%$ & 18 & $27,69 \%$ & 47 & $72,31 \%$ \\
\hline
\end{tabular}

Tabel 1 menunjukkan bahwa pada kelas eksperimen frekuensi siswa kategori n-gain tinggi sebanyak 1 atau $1,52 \%$ siswa sedangkan pada kelas kontrol tidak ada siswa yang berkategori n-gain tinggi, begitu juga pada kategori sedang pada kelas eksperimen jumlah siswa lebih banyak dibanding kelas kontrol yaitu sebanyak 51 atau $77,27 \%$ siswa untuk kelas eksperimen dan 18 atau $27,69 \%$ siswa untuk kelas kontrol, sementara pada kategori rendah, jumlah siswa pada kelas eksperimen lebih sedikit dibandingkan dengan kelas kontrol yaitu sebanyak 14 atau $21,21 \%$ siswa untuk kelas eksperimen dan 47 atau
$72,31 \%$ untuk kelas kontrol. Sehingga dapat disimpulkan bahwa peningkatan kemampuan berargumen siswa kelas eksperimen lebih tinggi daripada kelas kontrol.

Peningkatan skor rata-rata kemampuan berargumenyang menerapkan pembelajaran model $5 \mathrm{E}$ adalah sebesar $40 \%$ dengan kategori sedang. Hal ini membuktikan bahwa pembelajaran yang memuat tahapan $5 \mathrm{E}$ yang dintegrasikan dengan pendekatan saintifik dapat meningkatkan kemampuan berargumen siswa khususnya pada materi ekologi.

Meningkatnya kemampuan berargumen dalam penelitian ini sesuai 
dengan pendapat Suppe (2000) dan Osborne dkk., (2007) bahwa argumentasi ilmiah adalah kemampuan mengkomunikasikan dan mengkoordinasi fakta dan teori untuk memberikan penjelasan yang lebih mendalam tentang suatu model, prediksi atau suatu evaluasi. Argumentasi adalah eksplorasi yang sistimatis dari suatu konfirmasi teoritis melalui koordinasi bukti-bukti yang menggambarkan hasil observai empiris atau hasil eksperimen tentang fenomena alam (Bell dan Linn, 2007).

$$
\text { Kemampuan berargumen }
$$
merupakan indikator hasil belajar yang dicapai siswa dalam proses pembelajaran. Hasil belajar siswa berkaitan dengan kemampuan siswa dalam menyerap dan memahami bahan kajian yang diajarkan. Hasil belajar dapat dijadikan sebagai tolok ukur keberhasilan pembelajaran (Usman, 1993). Selanjutnya Usman (1993) menyatakan bahwa indikator yang dapat dijadikan tolok ukur keberhasilan kegiatan belajar mengajar adalah: 1) daya serap terhadap bahan pelajaran yang diajarkan mencapai prestasi tinggi, baik individu maupun kelompok, 2) perilaku yang digunakan dalam tujuan pembelajaran khusus yang telah dicapai siswa baik individu maupun kelompok

Hasil uji normalitas data dengan statistik parametrik KolmogorovSmirnov tes menunjukkan bahwa data pada seluruh perlakuan berdistribusi normal. Demikian pula dengan hasil uji homogenitas data dengan Levene's test menunjukkan bahwa koefisien statistik Leven's untuk kemampuan berargumen adalah 0,526. Angka tersebut lebih besar dari 0,05 dan memberikan makna bahwa varian data pada semua perlakuan adalah homogen, sehingga data dapat dianalisis dengan tehnik ujit. Hasil uji-t terhadap kemampuan berargumen dari dua perlakuan eksperimen dan kontrol disajikan pada Tabel 2.

Tabel 2 Hasil Uji-t Kemampuan Berargumen

\begin{tabular}{llccccc}
\hline & Df & $\begin{array}{c}\text { Mean } \\
\text { Diference }\end{array}$ & $\begin{array}{c}\text { Std Error } \\
\text { Diference }\end{array}$ & t & $\begin{array}{c}\text { Sig } \\
\text { (2-talled) }\end{array}$ \\
\hline Posttes_KBA & $\begin{array}{l}\text { equal variances } \\
\text { assumed }\end{array}$ & 129 & 4,92681 & 1,09931 & 4,482 & 0,000 \\
& $\begin{array}{l}\text { equal variances } \\
\text { not assumed }\end{array}$ & 128,85 & 4,92681 & 1,09931 & 4,482 & 0,000 \\
\hline
\end{tabular}


Data pada Tabel 2 menunjukkan bahwa ada pengaruh pembelajaran model 5E melalui pendekatan saintifik terhadap kemampuan berargumen siswa pada materi ekologi. ( $t_{\text {hitung }}=$ $4,482$ dan $p=0,000)>0,05$. Hasil ini mengindikasikan bahwa kemampuan berargumen siswa yang belajar dengan model 5E melalui pendekatan saintifik berbeda signifikan dengan siswa yang belajar dengan model EEK.

Hasil uji-t kemampuan berargumen, diperoleh nilai $t_{\text {hitung }}$ sebesar4,482 dengan angka signifikansi sebesar 0,000 lebih kecil dari 0,05. Hasil ini dapat diinteprestasikan bahwa hipotesis awal (Ho) yang menyatakan "Tidak terdapat pengaruh pembelajaran model $5 \mathrm{E}$ melalui pendekatan saintifik terhadap kemampuan berargumen siswa pada materi ekologi" ditolak, dengan kata lain "Terdapat pengaruh pembelajaran model 5E melalui pendekatan saintifik terhadap kemampuan berargumen siswa pada materi ekologi."

\section{Hasil Respon Siswa}

Hasil analisis respon siswa terhadap pembelajaran dengan menggunakan Model 5E melalui pendekatan saintifik menunjukkan bahwa respon siswa terhadap pembelajaran berada pada kategori sangat baik, hal ini ditunjukkan oleh rata-rata nilai skor yang diberikan siswa sebesar 3,85, skor ini berada pada kategori sangat baik dari kriteria skor yang dibuat $(3,26-4,00$, sangat baik; 2,51-3,25, baik; 1,76-2,50, kurang baik; 1,00-1,75, tidak baik), artinya pembelajaran dengan menggunakan model 5E melalui pendekan saintifik memberikan dampak positif kepada siswa dalam mempelajari materi ekologi.

\section{Hasil Penilaian Observer}

Hasil penilaian keterlaksanaan langkah-langkah pembelajaran model 5E melalui pendekatan saintifik menunjukkan keterlaksanaan RPP pada pertemuan I sampai IV untuk penggunaan perangkat pembelajaran model 5E melalui pendekatan saintifik dan EEK telah dilakukan dengan sangat baik dengan rata-rata nilanya 3,9. Hal ini berarti proses pembelajaran sesuai dengan Rencana Pelaksanaan Pembelajaran.

\section{SIMPULAN}

Dari pembahasan di atas dapat disimpulkan bahwa terdapat pengaruh yang signifikan pembelajaran model $5 \mathrm{E}$ 
melalui pendekatan saintifik terhadap kemampuan berargumen siswa pada materi ekologi $(\mathrm{t}=4,482, \mathrm{p}=0,000)$.

\section{DAFTAR PUSTAKA}

Anonim. 2011. Mata Pelajaran Science. Kementrian Pendidikan Nasional. Direktorat Pendidikan Dasar. Direktorat Pembina Sekolah Menengah Pertama. Jakarta: Quality Endorsed Company.

Bass, J. E Contat, T.L. dan Carin, A. A. 2009. Teaching Science as Inquiry. Boston: Pearson.

Bell, P., dan Linn, M. C., 2007. Scientific Argument as Learning Artifact: Designning for Learning from the Web with KIE. International Journal of Science Education.

(Online): http://www.designbasedresearch. org/ reppubs/bell-Linn.pdf, Diakses 20 Maret 2018.

Chankian, Jeeraporn, Adisak S, dan Penkae T. 2012. Science Curriculum Development on Environmental Conservation, with an Emphasis on the Promotion of Critical Thinking Skills for Mathayomsuksa 1 Students. European Journal of Scientific Research, (Online): 67 (4), http:// www.european journalofscientificresearch.com/I SSUES/EJSR_67_4_03.pdf, Diakses 4 Desember 2012.

Corebima, A. D. 2005. Keterampilan Proses: Pemberdayaan dan Asesmen. Makalah disajikan dalam Workshop bagi Mahasiswa dan Guru Pelaksana PTK A2 di Batu, Malang, 24 Juni 2005
Deming, J.C., dan M.S. Cracolice. 2004. Learning How to Think. The Science Teacher. Dick, W,

Gronlund, N.E dan R.L Linn., 1990. Measurement and Evaluation in Teaching. $6^{\text {th }}$. Ed. New York: MacMillan Publishing Company.

Jufri, A.W. dan Jekti, S. D. D. 2010. Efektifitas Pembelajaran Sains Berbasis Inkuiri dengan Strategi Kooperatif dalam Meningkatkan Keterampilan Berpikir Siswa SMP. Jurnal Pendididkan dan Pembelajaran. 17 (2). Oktober 2010.

Mangao, D. D. 2011. Enhancing Higher Order Thinking Skill in Secondary ScienceVia Information and Communication Technology. Penang. Southeast Asian Minister of Education Organizasion. Regional Center for Education in Science and Mathematics.

Osborne, J, Erduran, S, Simon, S. 2007. Enhancing The Quality of Argument in School Science. School Science Review, June 2001, 82(301)

Permendiknas Nomor 22 Tahun 2006 tentang Standar Isi.

Suppe, F. 2000. Understanding Scientific Theories: An Assessment of Developments 1969-1998. Philosophy of Science. (Online) https://www.princeton.edu/ hhal vors/teaching/phi520_f2012/Sup pe 2000. pdf, Diakses 25 Pebruari 2018

Sutrisno, J. 2010. Menggunakan Keterampilan Berpikir Untuk Meningkatkan Mutu Pembelajaran. (Online): (http// www.scribd.com/doc/54977805/ 


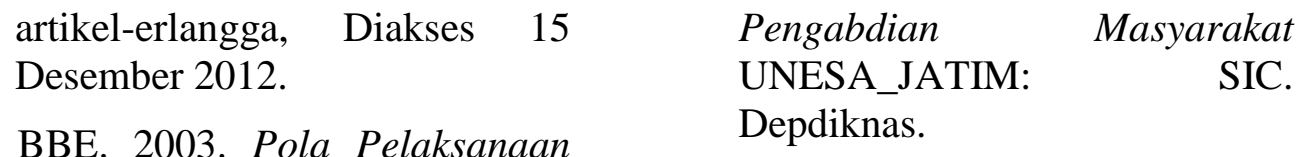

TIM BBE. 2003. Pola Pelaksanaan Pendidikan Kecakapan Hidup, Usman, U. M. 1996. Menjadi Guru Melalui Pendekatan Pendidikan Berbasis Luas. Lembaga Profesional. Bandung: Gramedia. 